\title{
Waste and Resource Management: Referees 2019
}

The following is a list of referees who have reviewed papers for Waste and Resource Management between 1 January 2019 and 31 December 2019. The Institution of Civil Engineers is very grateful for their assistance.

We are continually looking for suitable reviewers for papers submitted to Waste and Resource Management. Papers published in the Proceedings of the ICE must be submitted to at least two independent referees to judge accuracy, style, impact, importance and interest.

Konstantinos Abeliotis

Alev Akpinar Borazan

Hajar Bakraouy

Francois Buyle-Bodin

Veronica Caprai

Jeff Cooper

Robin Curry

Colin Davie

Maria Alzira Dinis

\author{
Seda Durukan \\ Simon Goldsmith \\ Rodolfo Gomes \\ Andrew Hursthouse \\ Sivakumar Kandasami \\ Sudarshan Kore \\ Sunil Kumar \\ Katia Lasaridi \\ Anne Morrissey
}

If you are interested in reviewing articles on any topic related to waste and resource management, please submit your name, qualifications or $\mathrm{CV}$, and areas of expertise. We are in need of individuals who will agree to review papers in a timely fashion (within 3 to 4 weeks of receipt) and provide confidential feedback to the Editorial Advisory Panel concerning the quality of the paper and any suggested revisions that would be appropriate.

If you are such a person, please contact Abiola Lawal (tel.: +44 (0)207 665 2249; e-mail: abiola.lawal@ice.org.uk) for more information on the referee process.

$\begin{array}{ll}\text { Opeyemi Oluwatuyi } & \text { Ilaria Schiavi } \\ \text { Fernando Pacheco-Torgal } & \text { John Skinner } \\ \text { Suneel Pandey } & \text { Karel Van Acker } \\ \text { Parimal Parikh } & \text { Bu Wang } \\ \text { Marcelo Patrão } & \text { Kristine Wichuk } \\ \text { Stefan Pickl } & \text { Karl Williams } \\ \text { William Powrie } & \text { Jonathan Wong } \\ \text { Murray Reid } & \text { Ryan Woodard } \\ \text { Keith Riley } & \text { Lingling Xu }\end{array}$

